\title{
A STUDY ON SURGICAL SITE INFECTION: FACTORS RESPONSIBLE FOR SURGICAL SITE INFECTIONS FOLLOWING EMERGENCY NONTRAUMATIC ABDOMINAL OPERATIONS
}

\section{Dr. Om Prakash Pawar}

\section{Dr. Ashish*}

\section{MBBS,MS (General Surgery),Sr(General Surgery-Skmch, Muzaffarpur.}

Senior Resident, Department of Neurosurgery, CMC Ludhiana.

${ }^{*}$ Corresponding Author

Dr.Änkita Khurana MBBS, Junior Resident (General Surgery), CMC Ludhiana.

ABSTRACT BACKGROUND: Surgical site infection is the most important and preventable cause of infections in surgical patients. It determines the morbidity and mortality in post -operative patients. Determination of modifiable factors can aid in modifying the course of post-operative period. The focus of this study is on the factors and organisms predisposing patient to surgical site infections. MATERIAL AND METHODS: A total of 140 cases undergoing emergency non traumatic abdominal operations were included and the variable factors were determined .RESULTS: Most of the patients $(89.29 \%$ ) were in between $10-49$ years. Rate of SSI was highest $26.47 \%$ (9 among 34 ) in the 40 - 49 years age group. The rate of SSI was as high as 15 among 46 (32.61 \%) dirty cases. Most of the infections $(91.66 \%)$ were started between 4 th and 8th post operative days (POD) and it was highest 8 (33.33\%) on 5th POD. CONCLUSION: Multiple host, environment and infective organism related factors determine the outcome of surgery

\section{KEYWORDS : surgical site infection, emergency non-traumatic abdominal operations, post op day}

\section{INTRODUCTION}

Surgical Site Infections (SSIs) result from bacterial contamination during or after a surgical procedure. Among surgical patients, surgical site infections are the most frequent cause of such infections, accounting for $38 \%$ of the total .Surgical site infection is preventable in most of the cases if proper assessment and appropriate measures are taken by the surgeons, patients and others in the perioperative period. This study's findings will play an important role to reduce the infection rate and thereby reduce the morbidity and mortality.

\section{MATERIALS AND METHODS}

In our study, 140 cases presenting to the Department of Surgery in Casualty and undergoing emergency non traumatic abdominal operations in Darbhanga medical college and hospital, laheriasarai were studied. This descriptive type of cross sectional study was conducted in Upgraded Department of Surgery, Darbhanga Medical College \& hospital, Laheriasarai. Patients with trauma were excluded from the study.

\section{RESULTS AND ANALYSIS}

Table I: Age distribution of the patients.

\begin{tabular}{|c|c|c|}
\hline Age in years & Number of patients & Percentage (\%) \\
\hline $10-19$ & 31 & 22.14 \\
\hline $20-29$ & 30 & 21.42 \\
\hline $30-39$ & 30 & 21.42 \\
\hline $40-49$ & 34 & 24.28 \\
\hline $50-59$ & 9 & 6.43 \\
\hline $60-69$ & 6 & 4.29 \\
\hline Total & 140 & 100.00 \\
\hline
\end{tabular}

Mean $\pm \mathrm{SD}=(32.93 \pm 3.79)$ years.

It was observed that age of 140 patients ranged from 13-65 years. Most of the patients (89.29 \%) were in between 10-49 years.

Table II: Surgical Site Infection (SSI) distribution by different age groups

\begin{tabular}{|c|c|c|c|}
\hline \multirow{2}{*}{ Age in years } & \multicolumn{2}{|c|}{ SSI status } & \multirow{2}{*}{ Total } \\
\cline { 2 - 3 } & Yes & No & \\
\hline $10-19$ & $5(16.13)$ & $26(83.87)$ & $31(100.00)$ \\
\hline $20-29$ & $2(6.67)$ & $28(93.33)$ & $30(100.00)$ \\
\hline
\end{tabular}

\begin{tabular}{|c|c|c|c|}
\hline $30-39$ & $5(16.67)$ & $25(83.33)$ & $30(100.00)$ \\
\hline $40-49$ & $9(26.47)$ & $25(73.53)$ & $34(100.00)$ \\
\hline $50-59$ & $2(22.23)$ & $7(77.77)$ & $9(100.00)$ \\
\hline $60-69$ & $1(16.67)$ & $5(83.33)$ & $6(100.00)$ \\
\hline Total & $24(17.14)$ & $116(82.86)$ & $140(100.00)$ \\
\hline
\end{tabular}

${ }^{*}$ Figures within parentheses indicate percentage.

It was observed that rate of SSI in different age groups were as follows: 5 (16.13\%) in the $10-19$ years, $2(6.67 \%)$ in the $20-29$ years, $5(16.67 \%)$ in the 30 - 39 years, $9(26.47 \%)$ in the $40-49$ years, $2(22.23 \%)$ in the $50-59$ years and $1(16.67 \%)$ in the 60 69 years. It was highest $26.47 \%$ (9 among 34 ) in the $40-49$ years age group.

Male, $89,63.57 \%$

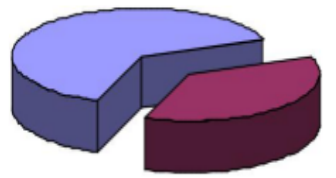

n. Male

- Female

Female, $51,36.43 \%$

Regarding sex distribution, out of 140 patients, 89 (63.57\%) were male and 51 (36.43\%) were female. Male-female ratio was 1.74:1.

Table III: Surgical Site Infection (SSI) distribution by Sex

\begin{tabular}{|c|c|c|c|}
\hline \multirow{2}{*}{ Sex } & \multicolumn{2}{|c|}{ SSI status } & \multirow{2}{*}{ Total } \\
\cline { 2 - 3 } & Yes & No & \\
\hline Male & $16(17.98)$ & $73(82.02)$ & $89(100.00)$ \\
\hline Female & $8(15.69)$ & $43(84.31)$ & $51(100.00)$ \\
\hline Total & $24(17.14)$ & $116(82.86)$ & $140(100.00)$ \\
\hline
\end{tabular}

* Figures within parentheses indicate percentage.

It was observed that rate of SSI in different age groups were as follows: 5 (16.13\%) in the $10-19$ years, $2(6.67 \%)$ in the $20-29$ years, $5(16.67 \%)$ in the 30 - 39 years, $9(26.47 \%)$ in the $40-49$ years, $2(22.23 \%)$ in the $50-59$ years and $l(16.67 \%)$ in the 60 69 years. It was highest $26.47 \%$ (9 among 34$)$ in the $40-49$ years age group. 
Regarding sex distribution, out of 140 patients, 89 (63.57\%) were male and $51(36.43 \%)$ were female. Male-female ratio was 1.74:1.

\section{DISTRIBUTION OF PATIENTS BY SEX}

Male, $89,63.57 \%$

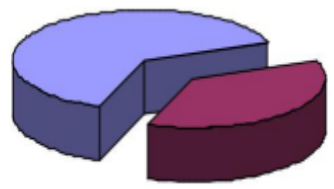

n Male

- Female

Female, $51,36.43 \%$

Table III: Surgical Site Infection (SSI) distribution by Sex

\begin{tabular}{|c|c|c|c|}
\hline \multirow{2}{*}{ Sex } & \multicolumn{2}{|c|}{ SSI status } & \multirow{2}{*}{ Total } \\
\cline { 2 - 3 } & Yes & No & \\
\hline Male & $16(17.98)$ & $73(82.02)$ & $89(100.00)$ \\
\hline Female & $8(15.69)$ & $43(84.31)$ & $51(100.00)$ \\
\hline Total & $24(17.14)$ & $116(82.86)$ & $140(100.00)$ \\
\hline
\end{tabular}

* Figures within parentheses indicate percentage.

Regarding sex distribution of SSI it was observed that among 89 male patients 16 (17.98\%) developed SSI, whereas among 51 female patients 8 ( $15.69 \%)$ developed SSI.

Table IV: Number of operations, SSIs and SSI rate (\%) by category.

\begin{tabular}{|c|c|c|c|}
\hline \multirow[t]{2}{*}{ Types of operations } & \multicolumn{2}{|c|}{ Status of SSI } & \multirow[t]{2}{*}{ Total } \\
\hline & Yes & No & \\
\hline Appendicectomy & $5(8.33)$ & $55(91.67)$ & $60(100.00)$ \\
\hline $\begin{array}{c}\text { Adhesiolysis or resection } \\
\text { and }\end{array}$ & \multirow[t]{2}{*}{$3(10.00)$} & \multirow[t]{2}{*}{$27(90.00)$} & \multirow[t]{2}{*}{$30(100.00)$} \\
\hline Anastomosis & & & \\
\hline $\begin{array}{c}\text { Repair of ileal perforation } \\
\text { Ileostomy }\end{array}$ & \multirow[t]{2}{*}{$8(42.10)$} & \multirow[t]{2}{*}{$11(57.89)$} & \multirow[t]{2}{*}{$19(100.00)$} \\
\hline $\begin{array}{l}\text { and thorough peritoneal } \\
\text { toileting }\end{array}$ & & & \\
\hline $\begin{array}{c}\text { Repair of duodenal ulcer } \\
\text { perforation }\end{array}$ & \multirow[t]{2}{*}{$3(20.00)$} & \multirow[t]{2}{*}{$12(80.00)$} & \multirow[t]{2}{*}{$15(100.00$} \\
\hline $\begin{array}{l}\text { and thorough peritoneal } \\
\text { toileting }\end{array}$ & & & \\
\hline $\begin{array}{l}\text { Appendicectomy with } \\
\text { peritoneal }\end{array}$ & \multirow[t]{2}{*}{$4(33.33)$} & \multirow[t]{2}{*}{$8(66.66)$} & \multirow[t]{2}{*}{$12(100.00)$} \\
\hline Toileting & & & \\
\hline $\begin{array}{l}\text { Resection of Volvulus of } \\
\text { sigmoid colon }\end{array}$ & \multirow[t]{3}{*}{$1(50.00)$} & \multirow[t]{3}{*}{$1(50.00)$} & \multirow[t]{3}{*}{$2(100.00)$} \\
\hline $\begin{array}{c}\text { and primary anastomosis/ } \\
\text { Hartmans }\end{array}$ & & & \\
\hline Procedure & & & \\
\hline $\begin{array}{l}\text { Herniotomy and } \\
\text { herniorrhaphy }\end{array}$ & - & $2(100.00)$ & $2(100.00)$ \\
\hline Total & $\begin{array}{c}24 \\
(17.14)\end{array}$ & $116(82.86)$ & $\begin{array}{c}140 \\
(100.00)\end{array}$ \\
\hline
\end{tabular}

* Figures within parentheses indicate percentage.

Out of 140 patients with emergency nontraumatic abdominal operations, rate of SSI in different operations were observed. It was found that out of 60 acute appendicitis cases 5 (8.33\%) developed SSI, out of 30 small intestinal obstruction cases 3 $(10.00 \%)$ developed SSI, out of 19 ileal perforation cases 8 $(42.10 \%)$ developed SSI, out of 15 duodenal ulcer perforation $3(20.00 \%)$ developed SSI, out of 12 burst appendix cases 4 $(33.33 \%)$ developed SSI, out of 2 sigmoid volvulus cases 1 (50.00\%) developed SSI and it was nil between 2 obstructed inguinal hernia cases

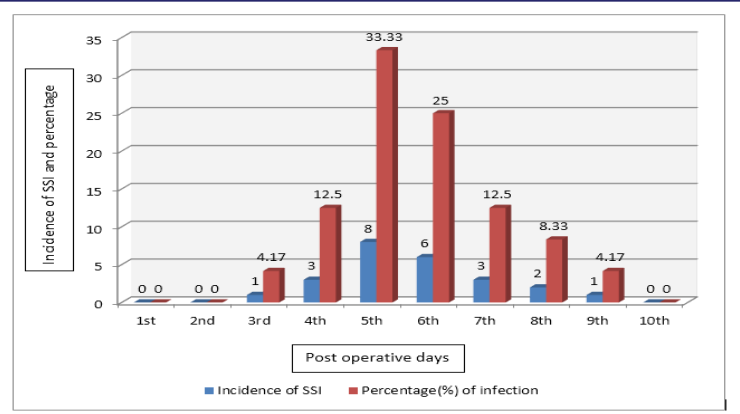

Figure 1: Bar diagram showing incidence of SSI after emergency Non traumatic abdominal surgery in different post operative days.

In relation to appearance of infection on postoperative days it was observed that most of the infections $(91.66 \%)$ were started between 4th and 8th post operative days (POD) and it was highest $8(33.33 \%)$ on 5th POD. Among a total of twenty four patients with surgical site infections, in only one patient (4.17 $\%)$ features of infection first appeared on 3rd POD and it was three $(12.50 \%)$ on 4 th, eight $(33.33 \%)$ on 5 th, six (25\%) on 6th, three $(12.50 \%)$ on 7 th, two $(8.33 \%)$ on 8 th and one $(4.17 \%)$ on 9th POD.

Table V: SSI distribution based on types of wounds by the degree of contamination.

\begin{tabular}{|c|c|c|c|}
\hline \multirow{2}{*}{ Types of wounds } & \multicolumn{2}{|c|}{ SSI status } & \multirow{2}{*}{ Total } \\
\cline { 2 - 3 } & Yes & No & \\
\hline Clean & $1(4.35)$ & $22(95.65)$ & $23(100.00)$ \\
\hline Clean contaminated & $5(8.33)$ & $55(91.67)$ & $60(100.00)$ \\
\hline Contaminated & $3(27.27)$ & $8(72.73)$ & $11(100.00)$ \\
\hline Dirty & $15(32.61)$ & $31(67.39)$ & $46(100.00)$ \\
\hline Total & $24(17.14)$ & $116(82.86)$ & $140(100.00)$ \\
\hline
\end{tabular}

${ }^{*}$ Figures within parentheses indicate percentage.

In relation to different types of wounds, by the degree of contamination, it was observed that among 140 cases 23 were clean wounds; SSI developed only in $1(4.35 \%)$ of these clean cases. There were 60 clean contaminated cases, among them SSI occurred in 5 (8.33\%); whereas SSI developed in 3 among $11(27.27 \%)$ contaminated wounds. The rate of SSI was as high as 15 among 46 (32.61 \%) dirty cases.

Table VI: Surgical site infection distribution based on presence of different co-morbidities.

\begin{tabular}{|c|c|c|c|}
\hline Types of & \multicolumn{2}{|c|}{ SSI status } & \multirow{2}{*}{ Total } \\
\hline co-morbidity & Yes & No & \\
\hline Malnutrition & $11(45.12)$ & $13(54.17)$ & $24(100.00)$ \\
\hline COPD & $2(28.57)$ & $5(71.43)$ & $7(100.00)$ \\
\hline Diabetes Mellitus & $2(33.33)$ & $4(66.67)$ & $6(100.00)$ \\
\hline Obesity & $1(33.33)$ & $2(66.67)$ & $3(100.00)$ \\
\hline Medical Jaundice & $1(50.00)$ & $1(50.00)$ & $2(100.00)$ \\
\hline Total & $\mathbf{1 7 ( 4 0 . 4 8 )}$ & $\mathbf{2 5}(59.52)$ & $\mathbf{4 2 ( 1 0 0 . 0 0 )}$ \\
\hline
\end{tabular}

* Figures within parentheses indicate percentage.

In 24 patients with malnutrition $11(45.12 \%)$ developed SSI, whereas among 7 patients with COPD $2(28.57 \%)$ developed SSI. 6 persons were diabetic, among them $2(33.33 \%)$ suffered from SSI. 3 persons were obese, 1 of them (33.33\%) developed SSI, whereas, lof $2(50.00 \%)$ persons suffering from medical jaundice developed SSI.

\section{DISCUSSION}

The study was carried out with a view to determine the factors responsible for surgical site infections (SSI) following emergency non-traumatic abdominal operation which will be helpful in reducing the rate of surgical site infection in the near future. 
Age of 140 patients ranged from 10-65 years. Most of the patients $(125,89.29 \%)$ were in between $10-49$ years; with mean age 32.93 years and standard deviation 3.79 years (Table I). In a similar study conducted in an Iranian teaching hospital average age of the patients was 46.70 years (Razavi et al.2005). Average age of the patients in the Iranian study was much higher than the present study. ${ }^{[1][2]}$

Regarding sex distribution of the patients, among the total 140 cases $89(63.57 \%)$ were male and 51 (36.43\%) were female. Male-female ratio was 1.74: 1(Fig.16). Rate of SSI was slightly higher in males, which was not statistically significant. This finding is consistent with that of Razavi et al. where they could not find any significant correlation between sex and SSI. Moreover, rate of SSI in males were $19.6 \%$, whereas in females it was $15.1 \%(P<0.093)$. So, SSI is not correlated with sex (Razavi et al. 2005) ${ }^{[2][3]}$

Out of 140 patients with emergency nontraumatic abdominal operations, rate of SSI in different operations were as follows: 5 among 60 (8.33\%) acute appendicitis cases, 3 among 30 (10.00\%) small intestinal obstruction, 8 among $19(42.10 \%)$ ileal perforation, 3 among $15(20.00 \%)$ duodenal ulcer perforation, 4 among 12 (33.33\%) burst appendix, 1 between $2(50.00 \%)$ sigmoid volvulus and no SSI occurred in 2 obstructed inguinal hernia cases. The highest rate of infection $(50.00 \%)$ was in volvulus cases and lowest in obstructed hernia operations (Table V). These findings were consistant with the result of Surgical Site Infection Survillance (SSIS) for general surgery which was published as Wexford General Hospital Surgical Site Infection (SSI) data report in 2009 showing number of SSI and rate of SSI (\%) by category of operations ${ }^{[3]}$

In relation to appearance of infection by features like fever, excessive pain, tenderness or discharge from the wound on postoperative days it was observed that most of the infections were started between 4 th and 8 th post operative days (PODs) and it was highest (33.33\%) on 5th POD. Among a total of twenty four patients with surgical site infection, in only one patient $(4.17 \%)$ features of infection first appeared on 3rd POD and it was three (12.50\%), eight (33.33\%), six (25\%), three $(12.50 \%)$, two $(8.33 \%)$ and one $(4.17 \%)$ persons who presents with features of infection on 4 th, 5 th, 6th, 7th, 8th and 9 th POD respectively. No infection started on 1 st, 2nd and 10th POD (Fig. 1). ${ }^{[4]}$

In relation to different types of wounds, by the degree of contamination, it was observed that among 140 cases 23 were clean wounds, SSI developed only in $1(4.35 \%)$ of these clean cases. There were 60 clean contaminated cases, among them SSI occurred in 5 (8.33\%); whereas SSI developed in 3 among $11(27.27 \%)$ contaminated wounds. The rate of SSI was as high as 15 among $46(32.61 \%)$ dirty cases. The difference was statistical significant $(P<0.01)$. It was revealed that the infection rate increased with that of degree of wound contamination (Table V). These findings were consistent with the findings of 10 years prospective study of 62,963 wounds by Cruse and Frood in 1980, where infection rate was $1.5 \%$, $7.7 \%, 15.2 \%$ and $40 \%$ in clean, clean contaminated, contaminated and dirty wounds respectively (Cruse and Frood 1980) ${ }^{[5]}$

In relation to co-morbidity, It was observed that infection rate was 45.12 per cent in clinically malnourished patients, whereas it was 28.57 per cent in COPD cases and 33.33 per cent in obese patients. Moreover, two patients underwent laparotomy with medical jaundice. Of them one (50\%) developed SSI. In addition six patients with diabetes mellitus underwent emergency abdominal surgery. Of them two patients $(33.33 \%)$ developed SSI (Table VI). Israelsson and Jonsson identified increased rate of SSI among overweight patients (Israelsson and Jonsson 1997). Another study by
Cruse and Frood showed that clean wound infection rate rises to $10.7 \%$ in patients with diabetes, $13.5 \%$ in obesity and $16.6 \%$ in malnourished patients (Cruse and Frood 1980).Moses M et al. and Zeenat Akter et al. also found that SSI rate increased among the patients with co-morbidities like obesity and diabetes mellitus. ${ }^{[5][6][7]}$

\section{CONCLUSIONS}

It has been revealed that multiple host factors (e.g. presence of co-morbidity including jaundice, diabetes, COPD, malnutrition, obesity etc.), environmental factors (e.g. duration of exposure of the wounds to the environment and degree of wound contamination) and various microorganisms (including E. Coli, S. Aureus, Klebsiella and pseudomonas) were responsible for surgical site infections. So, to prevent SSI emphasis should be given to all the important factors responsible for infection

\section{REFERENCES:}

1. Alberts, B., Johnson, A., Lewis, J., Raff, M., Roberts, K., and Walters, P., 2002. Molecular Biology of the Cell (4th ed.). New York and London: Garland Science. Available at: http:// www. ncbi. nlm. nih. gov/ books/ bv. fcgi? call= bv.View..Show TOC\&rid=mboc4.TOC\&depth=2.p 207-8

2. Razavi, S. M., Ibrahimpoor, M., Sabouri, A., Kashani, Jafarian A, 2005. Abomina surgical site infections: incidence and risk factors at an Iranian teaching hospital, BMC surgery, 5(2), 3-5.

3. Surgical Site Infection Survillance for general surgery, 2009. Wexford General Hospital Surgical Site Infection (SSI) data report, [ online ],8

4. Huda M. N., 2005. Wound infection profile in different non-traumatic emergency abdominal operations. Dissertation (FCPS). Bangladesh College of Physicians and Surgeons. P 60-61.

5. Cruse, P.J.E., Frood, R., 1980. The epidemiology of wound infection . Surgical clinics of North America, 60 (1), 27-40.

6. Israelsson, L. A., Jonsson, T., 1997. Overweight and healing of the midline incisions: the importance of suture technique .Eur J Surg., 163 (3), 175-80.

7. Zeenat Akter et al,STUDY ON RISK FACTORS AND ANTIBIOTICS USE PATTERN IN SSI,July 2012.EastWest University,D haka. 